\title{
Simple and rapid hydrogenation of $p$-nitrophenol with aqueous formic acid in catalytic flow reactors
}

\author{
Rahat Javaid*, Shin-ichiro Kawasaki, Akira Suzuki \\ and Toshishige M. Suzuki
}

Open Access

\author{
Full Research Paper \\ Address: \\ Research Center for Compact Chemical System, National Institute of \\ Advanced Industrial Science and Technology, AIST, 4-2-1 Nigatake, \\ Miyagino-ku, Sendai, Miyagi 983-8551, Japan \\ Email: \\ Rahat Javaid* - rahat-javaid@aist.go.jp; Toshishige M. Suzuki* - \\ tm-suzuki@aist.go.jp \\ * Corresponding author \\ Keywords: \\ catalytic tubular reactor; flow chemistry; formic acid; hydrogenation; \\ p-aminophenol; $p$-nitrophenol
}

\author{
Beilstein J. Org. Chem. 2013, 9, 1156-1163. \\ doi:10.3762/bjoc. 9.129 \\ Received: 22 February 2013 \\ Accepted: 23 May 2013 \\ Published: 14 June 2013 \\ This article is part of the Thematic Series "Chemistry in flow systems III". \\ Guest Editor: A. Kirschning \\ (C) 2013 Javaid et al; licensee Beilstein-Institut. \\ License and terms: see end of document.
}

\begin{abstract}
The inner surface of a metallic tube (i.d. $0.5 \mathrm{~mm}$ ) was coated with a palladium (Pd)-based thin metallic layer by flow electroless plating. Simultaneous plating of Pd and silver (Ag) from their electroless-plating solution produced a mixed distributed bimetallic layer. Preferential acid leaching of $\mathrm{Ag}$ from the $\mathrm{Pd}-\mathrm{Ag}$ layer produced a porous Pd surface. Hydrogenation of $p$-nitrophenol was examined in the presence of formic acid simply by passing the reaction solution through the catalytic tubular reactors. $p$-Aminophenol was the sole product of hydrogenation. No side reaction occurred. Reaction conversion with respect to $p$-nitrophenol was dependent on the catalyst layer type, the temperature, $\mathrm{pH}$, amount of formic acid, and the residence time. A porous and oxidized $\mathrm{Pd}(\mathrm{PdO})$ surface gave the best reaction conversion among the catalytic reactors examined. $p$-Nitrophenol was converted quantitatively to $p$-aminophenol within $15 \mathrm{~s}$ of residence time in the porous $\mathrm{PdO}$ reactor at $40{ }^{\circ} \mathrm{C}$. Evolution of carbon dioxide $\left(\mathrm{CO}_{2}\right)$ was observed during the reaction, although hydrogen $\left(\mathrm{H}_{2}\right)$ was not found in the gas phase. Dehydrogenation of formic acid did not occur to any practical degree in the absence of $p$-nitrophenol. Consequently, the nitro group was reduced via hydrogen transfer from formic acid to $p$-nitrophenol and not by hydrogen generated by dehydrogenation of formic acid.
\end{abstract}

\section{Introduction}

The flow reaction process enables continuous material production simply by feeding the reactants into one end of the reactor and obtaining the products from the other end [1-9]. Recently, we developed catalytic tubular reactors of less than $0.5 \mathrm{~mm}$ inner diameter, of which the interior surfaces were coated uniformly with thin $(1-2 \mu \mathrm{m})$ palladium $(\mathrm{Pd})$, platinum $(\mathrm{Pt})$, and rhodium $(\mathrm{Rh})$ layers by an electroless plating procedure $[10,11]$. These tubular reactors combined the merit of flow reaction 
processing with the catalytic properties of various metals. Unlike packed-bed catalysts, hollow tubular reactors can minimize the mass transfer resistance and therefore ensure a smooth flow of reactants without causing an undesirable pressure drop or clogging of reactor tubes. In addition, the tubular reactor offers a large surface-to-volume ratio, good mixing and heattransfer properties that enhance the reaction rate [5]. We have studied flow reactions, including the decomposition of hydrogen peroxide, oxidation of organic dyes, carbon-carbon coupling, and conversion of formic acid to hydrogen $\left(\mathrm{H}_{2}\right)$ and carbon dioxide $\left(\mathrm{CO}_{2}\right)$, using catalytic tubular reactors [10-13]

$p$-Aminophenol is an important intermediate produced in the syntheses of various chemicals including dyes, pharmaceuticals, and anticorrosive lubricants [14-16]. The catalytic hydrogenation of aromatic nitro compounds with $\mathrm{H}_{2}$ has been studied extensively in the presence of $\mathrm{Pd}, \mathrm{Pt}, \mathrm{Ni}$, and $\mathrm{Rh}$ metals [14,16$22]$. In the light of the commercial importance of $p$-aminophenol, improvement of catalytic performance was attempted by using nanoparticles (NPs) of $\mathrm{Au}, \mathrm{Pd}$, and $\mathrm{Ni}$ immobilized on various solid supports. Apart from the use of gaseous $\mathrm{H}_{2}$, the reduction of $p$-nitrophenol with sodium borohydride $\left(\mathrm{NaBH}_{4}\right)$ was studied catalyzed with core-shell $\mathrm{Au}-\mathrm{Pd}$
NPs and Au NPs [23-26]. Formic acid is another attractive $\mathrm{H}_{2}$ source because it is safe, easy to handle, and requires no highpressure equipment. Formic acid and formate have been used as effective $\mathrm{H}_{2}$ donors in the catalytic transfer hydrogenation of aromatic nitro compounds [27-31].

Here we attempted the hydrogenation of $p$-nitrophenol with formic acid in catalytic flow-through tubular reactors. Because Pd-based catalysts have usually been regarded as the most active catalysts [27,28,32], we modified the inner surface of tubular reactors with thin $\mathrm{Pd}$, porous $\mathrm{Pd}$, and their oxidized metal layers. Herein, we present a simple, rapid and convenient process for the reduction of $p$-nitrophenol, which is compatible with high reaction conversion under mild conditions.

\section{Results and Discussion}

\section{Fabrication of the catalytic tubular reactors}

Electroless plating is a simple and efficient methodology to coat the inner wall of a tubular reactor with various thin metal layers. Aside from the plating of a single Pd layer, we examined co-plating of $\mathrm{Pd}$ and $\mathrm{Ag}$ from their 9:1 (atomic ratio) mixed solution, as depicted in Figure 1a. Metal ions in the plating solution are stabilized against precipitation by complex forma-
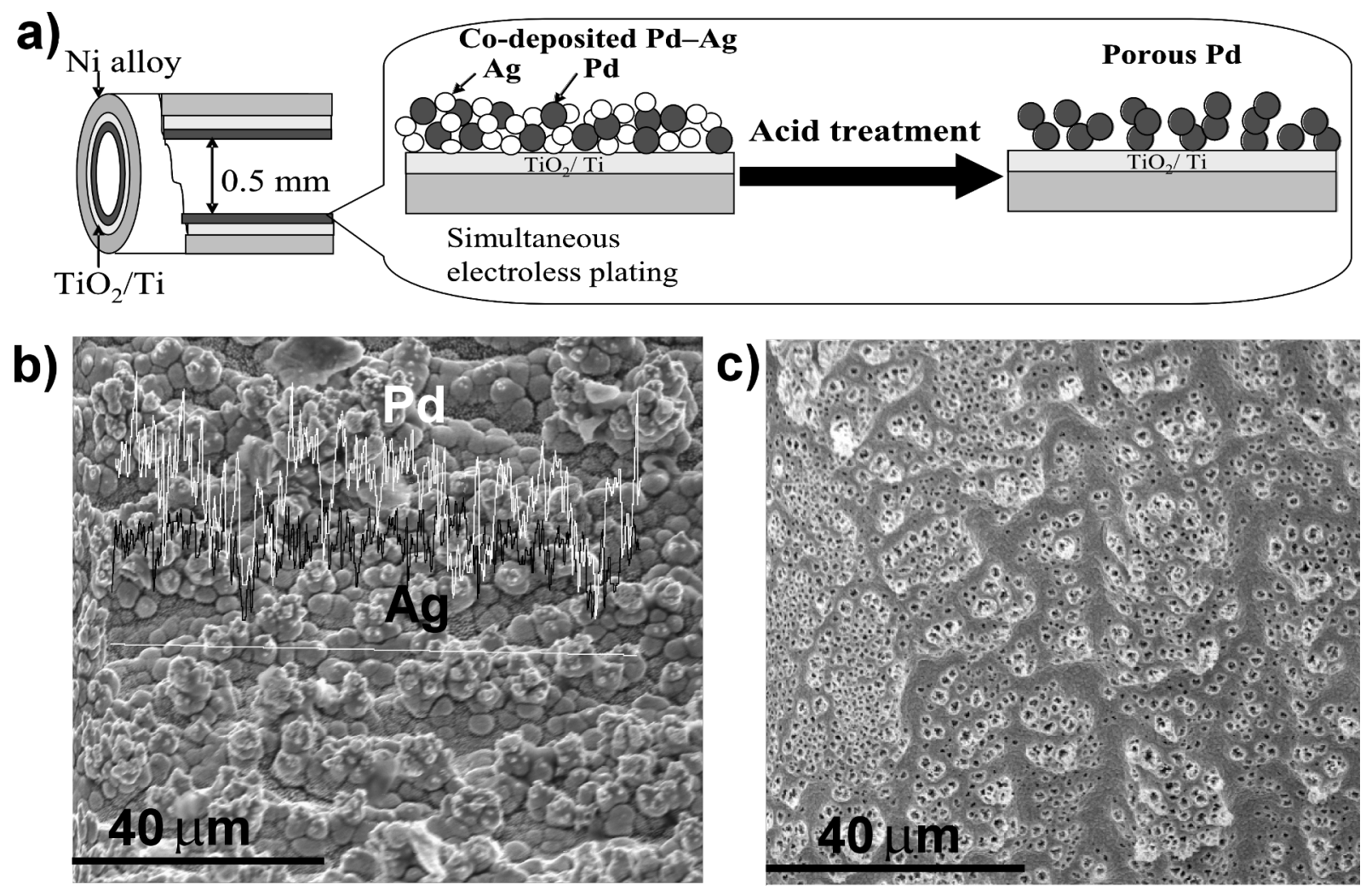

Figure 1: (a) Graphical presentation of Pd-Ag co-plating and sequential removal of $\mathrm{Ag}$ to give a porous Pd surface. (b) SEM image of Pd-Ag co-plated surface along with EDX presentation of Pd and $\mathrm{Ag}$ deposition. (c) Surface morphology of porous Pd. 
tion with EDTA and $\mathrm{NH}_{3}$, which also controls the deposition rate of the individual metal by modifying the redox potential [33]. SEM and EDX analysis of the plated layer indicated the mixed distribution of $\mathrm{Pd}$ and $\mathrm{Ag}$ over the inner surface (Figure 1b). It has been observed that Ag is preferentially plated. Therefore, a small excess of Ag (13\%) was deposited over the atomic ratio present in the plating solution [33]. When the Ag content exceeds $15 \%$ in the $\mathrm{Pd}-\mathrm{Ag}$ co-plating, the plating solution becomes considerably unstable and tends to give undesirable precipitation.

Selective dissolution of the less-noble element out of a bimetallic mixture or alloy results in the formation of a unique metallic sponge structure of the noble component [34,35]. We attempted to modify the reactor wall with a porous Pd layer. Continuous passage of $4 \mathrm{M} \mathrm{HNO}_{3}$ into the reactor with a $\mathrm{Pd}-\mathrm{Ag}$ co-plated layer preferentially dissolved Ag, leaving pores behind. Figure 1c shows an SEM image of the porous Pd surface after removal of Ag, where numerous pores are observed. Direct determination of the porosity of the porous metal layer was difficult because it firmly adhered and resisted removal from the inner surface of the narrow tube. Instead we conducted similar co-plating of Pd and Ag (9:1) on a glass surface. The plated $\mathrm{Pd}-\mathrm{Ag}$ film was peeled from the glass surface. Then Ag leached out by acid treatment of the film. The BET specific surface area and average pore diameter were determined respectively as $8.8 \mathrm{~m}^{2} \mathrm{~g}^{-1}\left(106 \mathrm{~m}^{2} \mathrm{~cm}^{-3}\right.$ as for volume base) and $9.4 \mathrm{~nm}$.

The oxidized palladium (PdO) surface often gave high catalytic activity [11,13,36-41]. Air oxidation of Pd and the porous Pd layer in the tubular reactors was conducted at $750{ }^{\circ} \mathrm{C}$ under air flow for $2 \mathrm{~h}$. The XPS analysis confirmed complete oxidation of the Pd surface to $\mathrm{PdO}$, as presented in our previous study [13].

\section{Hydrogenation of $p$-nitrophenol in the catalytic flow reactors}

The experimental setup of our flow reaction system is simple, as depicted in Figure 2, where a reactor tube loop was immersed in a water bath maintained at constant temperature. An aqueous solution containing $p$-nitrophenol and formic acid was supplied continuously from one end and collected in fractions at the other open end. The reaction solution flow is smooth and stable because the catalytic reactors are hollow tubes, avoiding the pressure drop and plugging.

The evolution of gas bubbles was observed during the reaction forming an alternate gas-liquid slug flow. GC analysis of the gas phase evidenced the evolution of $\mathrm{CO}_{2}$ as a sole product and $\mathrm{H}_{2}$ was not found. The hydrogenation reaction of $p$-nitrophenol was followed by UV-vis spectroscopy. The analytical UV-vis

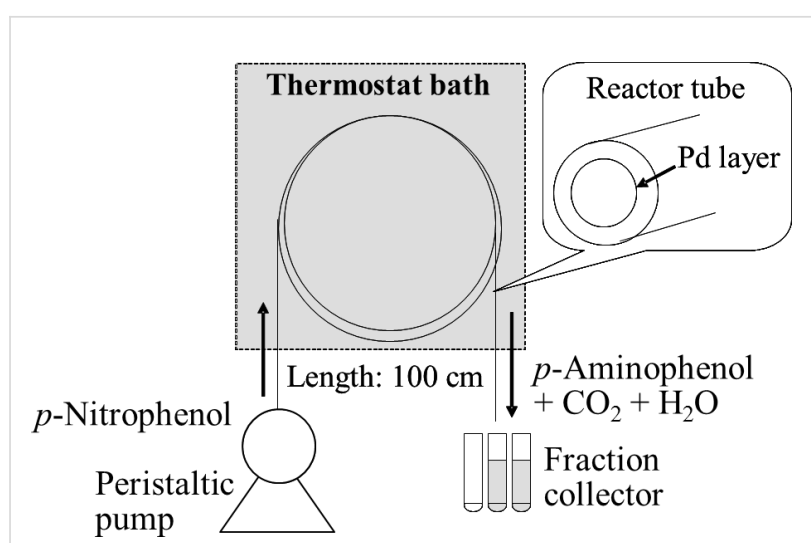

Figure 2: Schematic diagram of experimental setup used for the catalytic hydrogenation of $p$-nitrophenol.

peaks of $p$-nitrophenol and $p$-aminophenol are sufficiently separated both under acidic and basic conditions (Supporting Information File 1). The spectral difference between acidic and basic solutions is responsible for the association and dissociation of phenolic proton. The concentration of $p$-nitrophenol was determined by absorbance at $317 \mathrm{~nm}$ (acidic conditions) using the calibration curve. The presence of isosbestic points in the spectra (Supporting Information File 1) of the reaction mixture indicates that $p$-aminophenol is a sole product in the solution, and consequently no side reaction occurs as expressed in Scheme 1 .

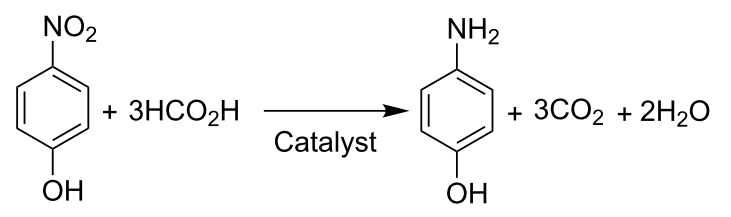

Scheme 1: Hydrogenation of $p$-nitrophenol with formic acid.

\section{Catalytic activity of the reactors}

Hydrogenation of $0.01 \mathrm{M}$ p-nitrophenol with $0.1 \mathrm{M}$ formic acid was conducted in aqueous solution at $30^{\circ} \mathrm{C}$ and $40{ }^{\circ} \mathrm{C}$ by using tubular reactors coated with $\mathrm{Pd}$, porous $\mathrm{Pd}$, metallic $\mathrm{Pd}-\mathrm{Ag}$ and porous $\mathrm{PdO}$. The $\mathrm{pH}$ of the aqueous reaction solution as prepared was 2.2. The flow rate was fixed to $0.8 \mathrm{~mL} \mathrm{~min}^{-1}$, which corresponds to $14.7 \mathrm{~s}$ of residence time in the tubular reactor. Figure 3 shows the reaction conversion of $p$-nitrophenol obtained by using the respective tubular reactors. The catalytic surface unquestionably contributed to facilitation of the reaction, because practically no reaction took place in the absence of the catalytic layer, even at $70{ }^{\circ} \mathrm{C}$. It is noteworthy that oxidation of the Pd surface improved the catalytic activity 


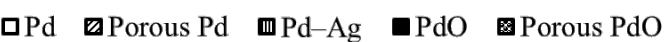

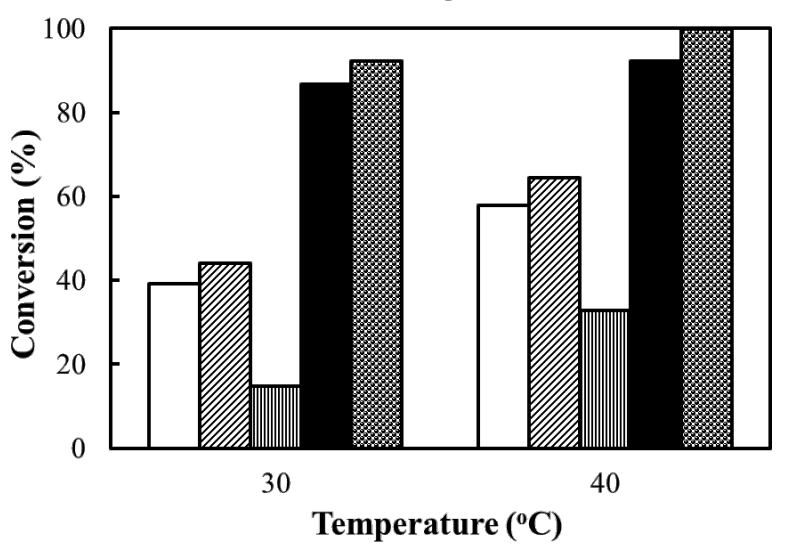

Figure 3: Influence of temperature on the conversion of $0.01 \mathrm{M} \mathrm{p}$-nitrophenol with $0.1 \mathrm{M}$ formic acid at $30^{\circ} \mathrm{C}$ and $40^{\circ} \mathrm{C}$. Tubular reactors coated with $\mathrm{Pd}, \mathrm{PdO}, \mathrm{Pd}-\mathrm{Ag}$, porous $\mathrm{Pd}$ or porous $\mathrm{PdO}$ were applied for demonstration of the catalytic activity. All experiments were conducted with $14.7 \mathrm{~s}$ residence time.

remarkably. The number of surface hydroxy groups increases with the oxidation of $\mathrm{Pd}$, allowing more intimate interaction with the reactants (see below). Addition of $13 \% \mathrm{Ag}$ to $\mathrm{Pd}$ greatly decreased the catalytic activity, presumably because $\mathrm{Ag}$ suppresses and inhibits the active Pd site. In fact, when Ag was removed by acid, the catalytic activity was revived. Moreover, the reactor with a porous $\mathrm{PdO}$ surface gave markedly superior conversion ( $>99 \%$ ) compared to that of the corresponding nonporous counterparts.

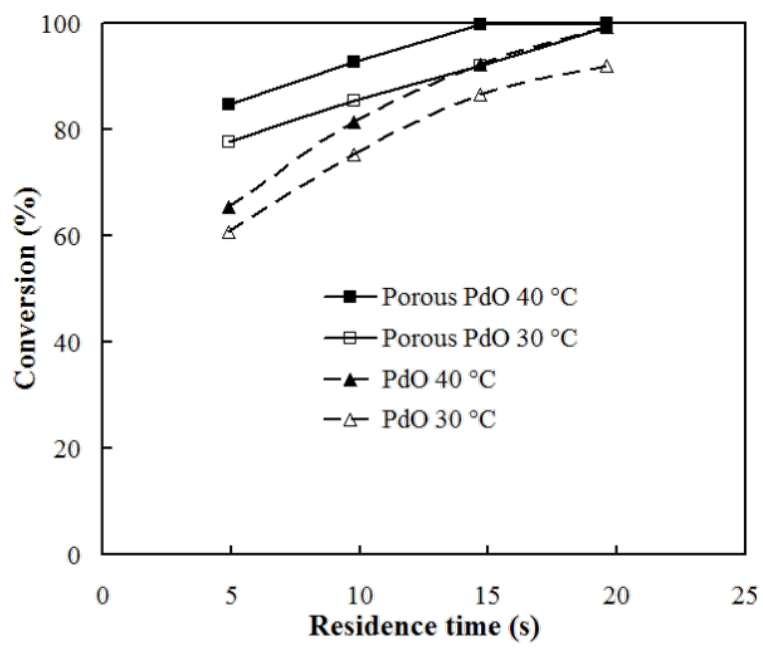

Figure 4: Effect of residence time on the conversion of $0.01 \mathrm{M} p$-nitrophenol with $0.1 \mathrm{M}$ formic acid at $30^{\circ} \mathrm{C}$ and $40{ }^{\circ} \mathrm{C}$ using $\mathrm{PdO}$ and porous-PdO-coated tubular reactors.
Superior catalytic activity of the porous surface was also confirmed by the effect of the residence time (flow rate) in the reactors. As presented in Figure 4, the reactor of porous PdO invariably attained higher conversion with shorter residence time than any other reactor. For example, $100 \%$ conversion was attained after $14.7 \mathrm{~s}$ residence time for porous $\mathrm{PdO}$, whereas nonporous $\mathrm{PdO}$ required $19.6 \mathrm{~s}$. The porous and rough reactor surface provided more contact opportunity with substrates, with which a much higher surface-area-to-volume ratio can be attained. The total amount of Pd present in the tube inner layer does not represent the concentration of active catalyst, since only surface metal atoms work as active sites. Therefore we estimated the number of surface Pd atoms using the observed surface area of porous $\mathrm{Pd}$, the number of closely packed Pd atoms in a face centred cubic (fcc) crystal unit, and the atomic radius of $\mathrm{Pd}(0.137 \mathrm{~nm})$ [32]. The catalytic activity expressed in terms of turnover frequency (TOF) was calculated to be around $320 \mathrm{~h}^{-1}$ (mol of substrate per mol of Pd site per hour) at $40{ }^{\circ} \mathrm{C}$. This value is much higher than those reported for the catalytic transfer hydrogenation of $p$-nitrophenol and benzyl acetate in a flow system [30,32].

We conducted the reaction while changing the concentration of formic acid and maintaining the $p$-nitrophenol concentration to $0.01 \mathrm{M}$. According to the reaction stoichiometry expressed in Scheme 1, three times the molar concentration of formic acid is necessary for the reduction of one mole of $p$-nitrophenol. In the present flow reaction, at least $0.05 \mathrm{M}$ formic acid was necessary to attain the maximum reaction conversion of $92.1 \%$ at $30{ }^{\circ} \mathrm{C}$ (Figure 5), which corresponds to a 1.7 times excess of the reducing agent to the $p$-nitrophenol. Further increases of concentration did not improve the reaction outcomes (Figure 5).

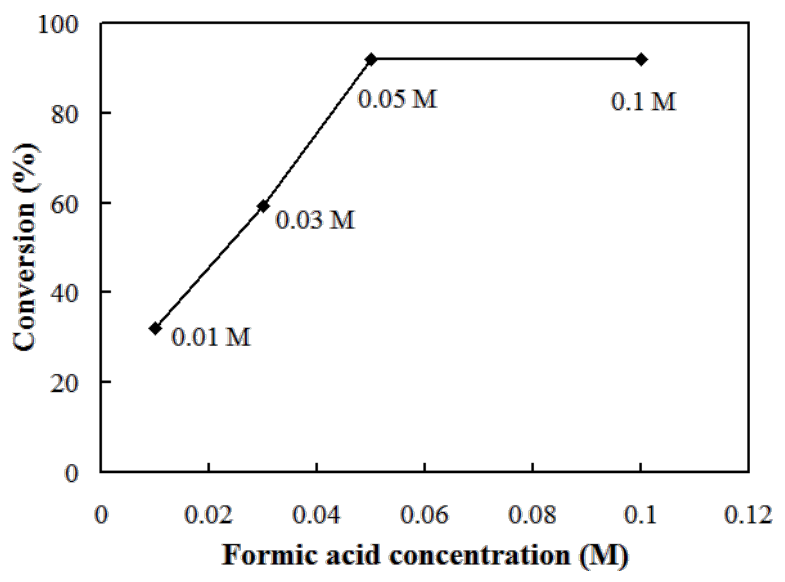

Figure 5: Effect of the concentration of formic acid on the conversion of $0.01 \mathrm{M} \mathrm{p}$-nitrophenol. The formic acid concentration varied: $0.01 \mathrm{M}$, $0.03 \mathrm{M}, 0.05 \mathrm{M}$ and $0.1 \mathrm{M}$. Porous-PdO-coated reactor was used at $30{ }^{\circ} \mathrm{C}$, with a residence time of $14.7 \mathrm{~s}$. 


\section{Transfer hydrogen from formic acid to $p$-nitro- phenol}

Dehydrogenation of formic acid and its subsequent reduction of nitro group is a possible reaction pathway. However as mentioned, $\mathrm{CO}_{2}$ was a sole product in the gas phase and $\mathrm{H}_{2}$ was not found even at an increased temperature of $70{ }^{\circ} \mathrm{C}$. To ensure that the nitro group is not reduced by $\mathrm{H}_{2}$ generated by dehydrogenation of formic acid, we conducted a control test where $p$-nitrophenol was absent. Notably when $p$-nitrophenol was not present in the reaction solution formic acid was not consumed at all at the present reaction temperature. In our previous study, more than $250{ }^{\circ} \mathrm{C}$ was necessary for the dehydrogenation of formic acid in the Pd-coated tubular reactor [13]. Consequently, we concluded that the nitro group was reduced in a transfer hydrogenation process and not by molecular $\mathrm{H}_{2}$ generated from the dehydrogenation of formic acid. In contrast to hydrogenation using gaseous $\mathrm{H}_{2}$, the present system using formic acid as hydrogen donor has the advantages of convenience and safety.

The PdO surface has a higher number of hydroxy groups than that of metallic Pd providing more opportunity for interaction sites with the substrates. This is in accordance with the higher reaction conversion attained by oxidized $\mathrm{PdO}$ reactor tube than that by the metallic Pd reactor tube. The reaction efficiency in a porous $\mathrm{PdO}$ reactor apparently depends on the $\mathrm{pH}$ of the reaction solution, as given in Figure 6. The decrease of $\mathrm{pH}$ produced markedly better conversion. By considering the $\mathrm{p} K_{\mathrm{a}}$ of formic acid (3.5), the acid form $\left(\mathrm{HCO}_{2} \mathrm{H}\right)$ contributes to the reaction conversion better than basic formate $\left(\mathrm{HCO}_{2}{ }^{-}\right)$does. $\mathrm{H}_{2}$ transfer from formic acid to a nitro compound has often been facilitated in the presence of a base, such as triethylamine and $\mathrm{NH}_{3}$ $[28,32,42-44]$. Therefore, the addition of such bases is usually necessary for transfer hydrogenation. As in the present case, base-free catalytic transfer hydrogenation of a nitro compound is a rather rare example $[31,45]$. One plausible explanation is a $\mathrm{pH}$ dependence of the electrostatic interaction between formic acid/formate and the catalytic surface. The oxidized Pd surface $(\mathrm{PdO})$ is equilibrated with $\mathrm{Pd}-\mathrm{OH}$ and $\mathrm{Pd}-\mathrm{O}^{-}$in aqueous solution depending on the $\mathrm{pH}$ [46]. Increase in the number of $\mathrm{Pd}-\mathrm{O}^{-}$ at high-pH region makes the surface more negative and inhibits the access of formate $\left(\mathrm{HCO}_{2}^{-}\right)$and phenolate $\left(\mathrm{NO}_{2}-\mathrm{Ph}-\mathrm{O}^{-}\right)$ anions, although at low $\mathrm{pH}$, such repulsion of $\mathrm{Pd}-\mathrm{OH}$ and the acidic reactants is suppressed.

\section{Long-term stability}

To evaluate the long-term stability and activity of the catalytic reactor, the reaction was run for $100 \mathrm{~h}$ at $30^{\circ} \mathrm{C}$ and another $100 \mathrm{~h}$ at $40^{\circ} \mathrm{C}$. In these experiments, a solution of $0.01 \mathrm{M}$ $p$-nitrophenol and $0.05 \mathrm{M}$ formic acid was fed continuously to the reactor tube at a fixed residence time of $14.7 \mathrm{~s}$. The solution was collected out of the reactor in fractions and the conversion

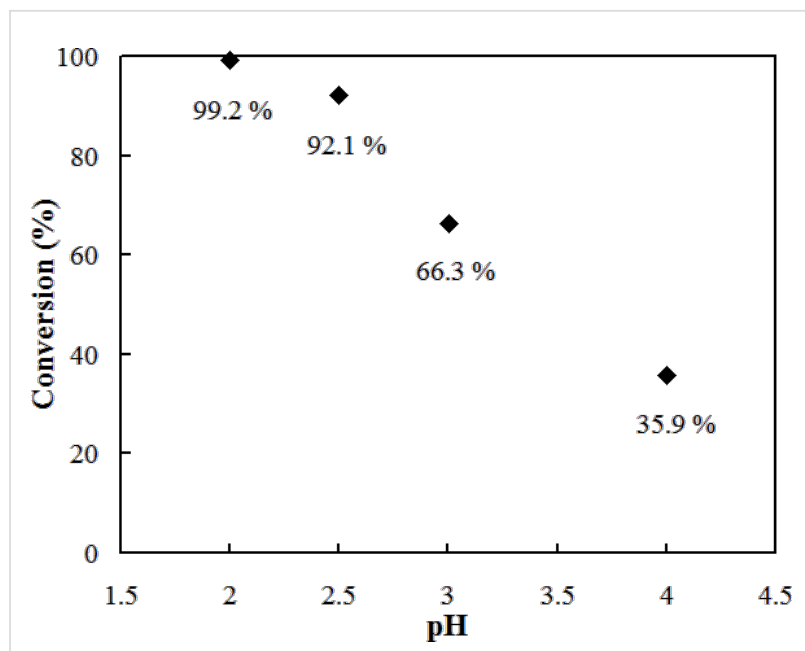

Figure 6: Effect of $\mathrm{pH}$ on the conversion of $0.01 \mathrm{M} p$-nitrophenol by using $0.05 \mathrm{M}$ formic acid. The porous $\mathrm{PdO}$ coated reactor was used at $30^{\circ} \mathrm{C}$ and a residence time of $14.7 \mathrm{~s}$.

was determined. As Figure 7 shows, the reaction was stable over this period. Palladium was not found in the reaction solution by the ICP-AES analysis, indicating that the leaching of Pd from the reactor tube was negligible during these experimental runs. Unlike other catalytic approaches for the reduction of $p$-nitrophenol [25,47-49], our catalytic flow system requires no product separation procedure. Moreover, we observed no decrease in the catalytic activity.

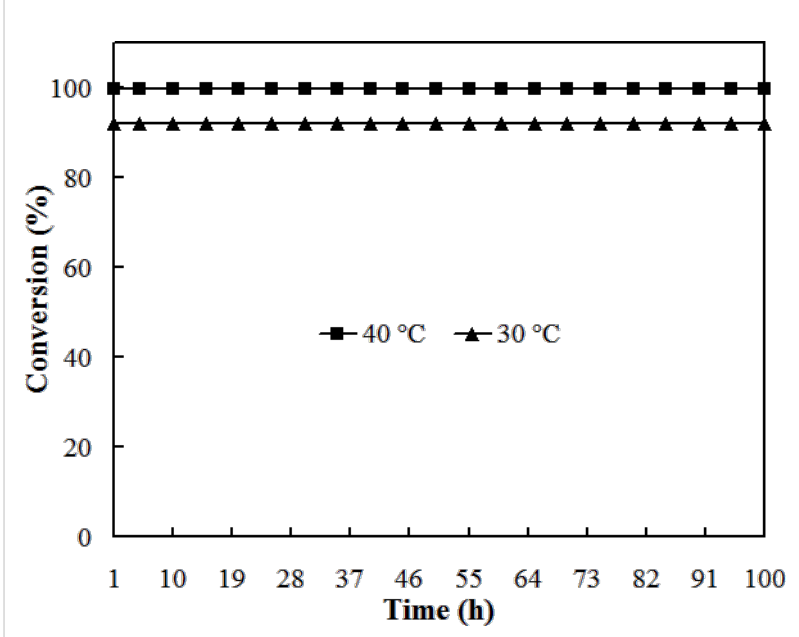

Figure 7: Long-term testing for continuous hydrogenation of $0.01 \mathrm{M}$ p-nitrophenol with $0.05 \mathrm{M}$ formic acid in the porous PdO-coated reactor. Residence time: $14.7 \mathrm{~s}$

\section{Conclusion}

A flow electroless plating procedure was employed to produce a thin metal-catalyst coating layer over the inner surface of a tubular reactor. Co-plating of Pd and Ag yielded mixed distrib- 
uted $\mathrm{Pd}$ and $\mathrm{Ag}$ inner surfaces, which further gave a porous $\mathrm{Pd}$ surface by preferential dissolution of $\mathrm{Ag}$ by $\mathrm{HNO}_{3}$. A hollow tubular reactor combined with the catalytic inner surface enabled rapid and continuous reaction under a smooth flow of reactants and products. The versatility of these catalytic tubular reactors was demonstrated through efficient and rapid reduction of $p$-nitrophenol by using formic acid. The nitro group is reduced in a transfer hydrogenation process and not by molecular $\mathrm{H}_{2}$ generated from dehydrogenation of formic acid. The porous and oxidized Pd surface showed better catalytic activity because of the increased surface area and roughness. No significant sign of deactivation of the catalyst or leaching of Pd was observed through $100 \mathrm{~h}$ continuous reaction, which demonstrates the robustness of the present catalytic reactors.

\section{Experimental \\ Materials and reagents}

Reagent-grade formic acid $\left(\mathrm{HCO}_{2} \mathrm{H}, 98 \%\right)$, p-nitrophenol, palladium acetate $\left[\mathrm{Pd}\left(\mathrm{CH}_{3} \mathrm{COO}\right)_{2}\right]$, silver nitrate $\left(\mathrm{AgNO}_{3}\right)$, disodium ethylenediamine tetraacetate (EDTA-Na $)$, ammonia $\left(\mathrm{NH}_{3}, 28 \%\right)$, hydrazine monohydrate, nitric acid $\left(\mathrm{HNO}_{3}, 60 \%\right)$ and hydrogen peroxide $\left(\mathrm{H}_{2} \mathrm{O}_{2}, 30 \%\right)$ were purchased from Wako Pure Chemical Industries Ltd. and were used without further purification.

\section{Fabrication of tubular reactors}

A double-layered tube (o.d. $1.6 \mathrm{~mm}$, i.d. $0.5 \mathrm{~mm}$, length $100 \mathrm{~cm}$ ) composed of Inconel 625 and titanium (Ti) inner layer (thickness $120 \mu \mathrm{m}$ ) was fabricated by E.S.Q. Co., Japan, by elongation of the titanium inlaid Inconel 625 piece by stretchdraw process, and used as the reactor support [11]. The Ti inner surface was oxidized to $\mathrm{TiO}_{2}$ with $\mathrm{H}_{2} \mathrm{O}_{2}$ under supercritical water conditions $\left(450{ }^{\circ} \mathrm{C}, 30 \mathrm{MPa}\right)$. $\mathrm{The}^{\mathrm{TiO}} 2$ surface, which is suitable for Pd plating, also acts as a barrier to prevent intermetallic diffusion of $\mathrm{Ti}$ and the metal catalyst. $\mathrm{The}^{\mathrm{TiO}} 2$ surface was activated with Pd seeds before electroless plating. Plating of Pd was then conducted according to the procedure described in previous reports [10-12]. By $5 \mathrm{~h}$ plating at $50{ }^{\circ} \mathrm{C}, 67.3 \mathrm{mg}$ of Pd was deposited, which corresponds to a Pd inner wall thickness of $3.6 \mu \mathrm{m}$. The Pd surface was oxidized by calcination of the tubular reactor at $750{ }^{\circ} \mathrm{C}$ for $2 \mathrm{~h}$ under air flow.

Co-plating of Pd and silver (Ag) was typically performed by passing $\left(0.5 \mathrm{~mL} \mathrm{~min}^{-1}\right)$ an aqueous solution containing $9 \mathrm{mM}$ $\mathrm{Pd}\left(\mathrm{CH}_{3} \mathrm{COO}\right)_{2}, 1 \mathrm{mM} \mathrm{AgNO} 3,0.15 \mathrm{M}$ EDTA-Na $2,4 \mathrm{M} \mathrm{NH}_{3}$, and $10 \mathrm{mM}$ hydrazine monohydrate through the reactor tube at $60{ }^{\circ} \mathrm{C}$. After $3 \mathrm{~h}$ plating, $67.7 \mathrm{mg}$ of $\mathrm{Pd}(87 \%)$ and $10.1 \mathrm{mg}$ of Ag $(13 \%)$ were deposited inside the tubular reactor. After plating, washing with water was conducted to remove the chemicals remaining inside the tube. The $\mathrm{Pd}-\mathrm{Ag}$ mixed layer thickness was estimated as ca. $4.2 \mu \mathrm{m}$.
Subsequent removal of $\mathrm{Ag}$ by passing $4 \mathrm{M} \mathrm{HNO}_{3}(840 \mathrm{~mL})$ at $25^{\circ} \mathrm{C}$ with a flow rate of $0.5 \mathrm{~mL} \mathrm{~min}{ }^{-1}$ gave the porous $\mathrm{Pd}$ surface as observed by SEM imaging. The remaining amounts of Pd and $\mathrm{Ag}$ were $48.1 \mathrm{mg}$ (94\%) and $2.9 \mathrm{mg}$ (5.7\%), respectively. We separately co-plated $\mathrm{Pd}$ and $\mathrm{Ag}$ film on a glass surface with the same chemical composition. Then the thin film $(3.5 \mu \mathrm{m})$ was peeled and treated with $4 \mathrm{M} \mathrm{HNO}_{3}$ and provided to the BET specific surface area and pore diameter measurements at $77 \mathrm{~K}$ by nitrogen absorption isotherm.

\section{Hydrogenation of $p$-nitrophenol}

A typical reaction procedure is the following, using the experimental setup depicted in Figure 2. The reactor tube and container of reaction stock solution were immersed in a water bath to maintain a constant temperature. The reaction was conducted at ambient pressure. An aqueous solution containing $p$-nitrophenol $(10 \mathrm{mM})$ and formic acid was fed into the tubular reactor $(100 \mathrm{~cm}$ long with inner volume of $196 \mu \mathrm{L})$ at a constant flow rate controlled by a peristaltic pump. The solution out of the reactor tube was collected in fractions and the UV-vis absorption spectra were measured. The analytical UV-vis peaks of substrate and product are sufficiently separated and the concentration of $p$-nitrophenol was ascertained by the absorbance at $317 \mathrm{~nm}$ using the calibration curve. The residence time was estimated from the volume of reaction solution at a fixed time divided by the inner volume of the reactor tube. Leaching of Pd from the reactor tube during the reaction was checked by inductively coupled plasma-atomic emission spectroscopy (ICP-AES) analysis of the fractionated reaction solution.

\section{Instruments}

The metal concentration was analyzed using ICP- atomic emission spectroscopy (ICP-AES, Model SPS 3100; SII Nano Technology Inc.). The morphology of the inner surface of the catalytic tubular reactors was observed by scanning electron microscopy (SEM) equipped with an energy-dispersive X-ray spectrometer (EDX, XL30S; Philips Co.). UV-vis absorption spectra were recorded at room temperature by using a spectrophotometer (U-3310; Hitachi). The collected gaseous products were analyzed by using a gas chromatograph (GC-8A; Shimadzu Corp.) equipped with thermal conductivity detector (TCD). A molecular sieve (5 $\AA$ ) column $(3 \mathrm{~mm} \times 6 \mathrm{~m})$ was used for $\mathrm{H}_{2}$ with argon as the carrier gas, whereas a Porapak-Q column $(3 \mathrm{~mm} \times 3 \mathrm{~m})$ was used coupled with helium as the carrier gas for $\mathrm{CO}_{2}$ analysis. The specific surface area and pore diameter of the porous Pd were determined volumetrically ( $\mathrm{N}_{2}$ adsorption) by using Belsorp MAX. Samples were degassed at $250{ }^{\circ} \mathrm{C}$ under vacuum prior to the measurement. 


\section{Supporting Information}

The Supporting Information features the isosbestic points in the UV-vis spectra of the reaction mixture indicating that $p$-aminophenol is the sole product and no side reaction occurs.

\section{Supporting Information File 1}

Analytical and spectral data.

[http://www.beilstein-journals.org/bjoc/content/ supplementary/1860-5397-9-129-S1.pdf]

\section{References}

1. Wiles, C.; Watts, P. Green Chem. 2012, 14, 38-54. doi:10.1039/c1gc16022b

2. Wegner, J.; Ceylan, S.; Kirschning, A. Adv. Synth. Catal. 2012, 354, 17-57. doi:10.1002/adsc.201100584

3. Wegner, J.; Ceylan, S.; Kirschning, A. Chem. Commun. 2011, 47, 4583-4592. doi:10.1039/c0cc05060a

4. Holladay, J. D.; Wang, Y.; Jones, E. Chem. Rev. 2004, 104, 4767-4790. doi:10.1021/cr020721b

5. Mason, B. P.; Price, K. E.; Steinbacher, J. L.; Bogdan, A. R.; McQuade, D. T. Chem. Rev. 2007, 107, 2300-2318. doi:10.1021/cr050944c

6. Garcia-Verdugo, E.; Liu, Z.; Ramirez, E.; Garcia-Serna, J.; Fraga-Dubreuil, J.; Hyde, J. R.; Hamley, P. A.; Polakoff, M. Green Chem. 2006, 8, 359-364. doi:10.1039/b515470g

7. Kirschning, A. Beilstein J. Org. Chem. 2011, 7, 1046-1047. doi:10.3762/bjoc.7.119

8. Oyamada, H.; Naito, T.; Kobayashi, S. Beilstein J. Org. Chem. 2011, 7, 735-739. doi:10.3762/bjoc.7.83

9. Bogdan, A. R.; Sach, N. W. Adv. Synth. Catal. 2009, 351, 849-854 doi:10.1002/adsc.200800758

10. Javaid, R.; Tanaka, D. A. P.; Kawanami, H.; Suzuki, T. M. Chem. Lett. 2009, 38, 146-147. doi:10.1246/cl.2009.146

11. Javaid, R.; Kawanami, H.; Chatterjee, M.; Ishizaka, T.; Suzuki, A.; Suzuki, T. M. Catal. Commun. 2010, 11, 1160-1164. doi:10.1016/j.catcom.2010.05.018

12. Javaid, R.; Kawanami, H.; Chatterjee, M.; Ishizaka, T.; Suzuki, A.; Suzuki, T. M. Chem. Eng. J. 2011, 167, 431-435. doi:10.1016/j.cej.2010.08.080

13. Javaid, R.; Kawasaki, S.; Ookawara, R.; Sato, K.; Nishioka, M.; Suzuki, A.; Suzuki, T. M. Appl. Catal., A: Gen. submitted.

14. Du, Y.; Chen, H.; Chen, R.; Xu, N. Appl. Catal., A 2004, 277, 259-264. doi:10.1016/j.apcata.2004.09.018

15. Corbett, J. F. Dyes Pigm. 1999, 41, 127-136. doi:10.1016/S0143-7208(98)00075-8

16. Rode, C. V.; Vaidya, M. J.; Chaudhari, R. V. Org. Process Res. Dev. 1999, 3, 465-470. doi:10.1021/op990040r

17. Vaidya, M. J.; Kulkarni, S. M.; Chaudhari, R. V. Org. Process Res. Dev. 2003, 7, 202-208. doi:10.1021/op025589w

18. Lu, H.; Yin, H.; Liu, Y.; Jiang, T.; Yu, L. Catal. Commun. 2008, 10 , 313-316. doi:10.1016/j.catcom.2008.09.015

19. Wang, J.; Yuan, Z.; Nie, R.; Hou, Z.; Zheng, X. Ind. Eng. Chem. Res. 2010, 49, 4664-4669. doi:10.1021/ie1002069
20. Yao, H.; Emmett, P. H. J. Am. Chem. Soc. 1959, 81, 4125-4132. doi:10.1021/ja01525a001

21. Yao, H.-C.; Emmett, P. H. J. Am. Chem. Soc. 1961, 83, 796-799. doi:10.1021/ja01465a011

22. Yao, H.-C.; Emmett, P. H. J. Am. Chem. Soc. 1962, 84, 1086-1091. doi:10.1021/ja00866a003

23. Venkatesan, P.; Santhanalakshmi, J. Nanosci. Nanotechnol. 2011, 1, 43-47. doi:10.5923/j.nn.20110102.08

24. Panigrahi, S.; Basu, S.; Praharaj, S.; Pande, S.; Jana, S.; Pal, A.; Ghosh, S. K.; Pal, T. J. Phys. Chem. C 2007, 111, 4596-4605. doi:10.1021/jp067554u

25. Kuroda, K.; Ishida, T.; Haruta, M. J. Mol. Catal. A: Chem. 2009, 298, 7-11. doi:10.1016/j.molcata.2008.09.009

26. Du, D.-Y.; Qin, J.-S.; Wang, T.-T.; Li, S.-L.; Su, Z.-M.; Shao, K.-Z.; Lan, Y.-Q.; Wang, X.-L.; Wang, E.-B. Chem. Sci. 2012, 3, 705-710. doi:10.1039/c2sc00586g

27. Brieger, G.; Nestrick, T. J. Chem. Rev. 1974, 74, 567-580. doi:10.1021/cr60291a003

28. Prasad, K.; Jiang, X.; Slade, J. S.; Clemens, J.; Repič, O.; Blacklock, T. J. Adv. Synth. Catal. 2005, 347, 1769-1773. doi:10.1002/adsc. 200505132

29. Yu, J.-Q.; Wu, H.-C.; Ramarao, C.; Spencer, J. B.; Ley, S. V. Chem. Commun. 2003, 678-679. doi:10.1039/b300074p

30. Xiang, Y.; Li, X.; Lu, C.; Ma, L.; Zhang, Q. Appl. Catal., A 2010, 375, 289-294. doi:10.1016/j.apcata.2010.01.004

31. Wienhöfer, G.; Sorribes, I.; Boddien, A.; Westerhaus, F.; Junge, K.; Junge, H.; Llusar, R.; Beller, M. J. Am. Chem. Soc. 2011, 133, 12875-12879. doi:10.1021/ja2061038

32. Rajagopal, S.; Spatola, A. F. Appl. Catal., A 1997, 152, 69-81. doi:10.1016/S0926-860X(96)00342-0

33. Tanaka, D. A. P.; Tanco, M. A. L.; Niwa, S.-i.; Wakui, Y.; Mizukami, F.; Namba, T.; Suzuki, T. M. J. Membr. Sci. 2005, 247, 21-27. doi:10.1016/j.memsci.2004.06.002

34. Rugolo, J.; Erlebacher, J.; Sieradzki, K. Nat. Mater. 2006, 5, 946-949. doi:10.1038/nmat1780

35. Tominaka, S.; Hayashi, T.; Nakamura, Y.; Osaka, T. J. Mater. Chem. 2010, 20, 7175-7182. doi:10.1039/c0jm00973c

36. Simplício, L. M. T.; Brandão, S. T.; Sales, E. A.; Lietti, L.; Bozon-Verduraz, F. Appl. Catal., B 2006, 63, 9-14. doi:10.1016/j.apcatb.2005.08.009

37. Meng, L.; Jia, A.-P.; Lu, J.-Q.; Luo, L.-F.; Huang, W.-X.; Luo, M.-F. J. Phys. Chem. C 2011, 115, 19789-19796. doi:10.1021/jp2056688

38. Lin, R.; Luo, M.; Xin, Q.; Sun, G. Catal. Lett. 2004, 93, 139-144. doi:10.1023/B:CATL.0000017067.19873.32

39. Hadi, A.; Yaacob, I. I. Catal. Today 2004, 96, 165-170. doi:10.1016/j.cattod.2004.06.118

40. Liu, X.; Liu, J.; Geng, F.; Li, Z.; Li, P.; Gong, W. Front. Chem. Sci. Eng. 2012, 6, 34-37. doi:10.1007/s11705-011-1163-3

41. Euzen, P.; Le Gal, J.-H.; Rebours, B.; Martin, G. Catal. Today 1999, 47, 19-27. doi:10.1016/S0920-5861(98)00280-6

42. Gowda, D. C.; Mahesh, B. Synth. Commun. 2000, 30, 3639-3644. doi:10.1080/00397910008086990

43. Gowda, D. C.; Gowda, A. S. P.; Baba, A. R.; Gowda, S. Synth. Commun. 2000, 30, 2889-2895. doi:10.1080/00397910008087439

44. Cortese, N. A.; Heck, R. F. J. Org. Chem. 1977, 42, 3491-3494. doi:10.1021/jo00442a008

45. Soltani, O.; Ariger, M. A.; Vázquez-Villa, H.; Carreira, E. M. Org. Lett. 2010, 12, 2893-2895. doi:10.1021/ol1008894 
46. Dougherty, G. M.; Rose, K. A.; Tok, J. B.-H.; Pannu, S. S.;

Chuang, F. Y. S.; Sha, M. Y.; Chakarova, G.; Penn, S. G.

Electrophoresis 2008, 29, 1131-1139. doi:10.1002/elps.200700448

47. Lu, X.; Bian, X.; Nie, G.; Zhang, C.; Wang, C.; Wei, Y. J. Mater. Chem. 2012, 22, 12723-12730. doi:10.1039/c2jm16559g

48. Rajesh, R.; Venkatesan, R. J. Mol. Catal. A: Chem. 2012, 359, 88-96. doi:10.1016/j.molcata.2012.04.001

49. Chi, Y.; Yuan, Q.; Li, Y.; Tu, J.; Zhao, L.; Li, N.; Li, X.

J. Colloid Interface Sci. 2012, 383, 96-102.

doi:10.1016/j.jcis.2012.06.027

\section{License and Terms}

This is an Open Access article under the terms of the Creative Commons Attribution License

(http://creativecommons.org/licenses/by/2.0), which permits unrestricted use, distribution, and reproduction in any medium, provided the original work is properly cited.

The license is subject to the Beilstein Journal of Organic Chemistry terms and conditions:

(http://www.beilstein-journals.org/bjoc)

The definitive version of this article is the electronic one which can be found at: doi:10.3762/bjoc.9.129 